\title{
Xenotransplantation of human cryopreserved parathyroid tissue isolated from parathyroid adenomas to normocalcemic rabbits
}

Erhan Ayșan¹, Yiğ̈it Düzköylü², İsmail Can³, Nur Büyükpınarbașılı

ABSTRACT Objective: Parathyroid allotransplantation is a new method for the treatment of permanent hypoparathyrodism. Adenoma cells are not used for transplantation because of the potential for functional or histopathologic transformation. In this study, we transplanted human adenomatous parathyroid cells to rabbits.

Material and Methods: Parathyroid adenoma tissue taken from a male patient was cryopreserved and transplanted into seven New Zealand white rabbits (mean weight, $3700 \pm 220 \mathrm{~g}$; mean age, 4.5 months) under immunosuppression. The levels of parathormone, calcium and phosphorus were measured before and after transplantation, and the parathyroid cells were observed histopathologically.

Results: Mean parathyroid hormone level was $0.5 \mathrm{pg} / \mathrm{dL}$ before transplantation and $6.6 \mathrm{pg} / \mathrm{dL}$ after transplantation $(p<0.05)$. Preoperative mean calciumlevel was $14.1 \mathrm{mg} / \mathrm{dL}$, and mean phosporus level was $3.5 \mathrm{mg} / \mathrm{dL}$ before transplantation while these values were $14.4 \mathrm{mg} / \mathrm{dL}$ and $3.3 \mathrm{mg} / \mathrm{dL}$, respectively, after transplantation $(\mathrm{p}>0.05)$. Morphologic transformation was not observed in parathyroid cells after transplantation.

Conclusion: In short-term observation, adenomatous parathyroid cells can function without malignant transformation. In the future, the preliminary methodology in this study may serve as a safe alternative for allotransplantation into patients with permanent hypoparathyroidism.

Keywords: Hypoparathyroidism, xenotransplantation, parathyroid adenoma

Cite this paper as: Ayşan E, Düzköylü Y, Can I, Büyükpınarbaşlı N. Xenotransplantation of human cryopreserved parathyroid tissue isolated from parathyroid adenomas to normocalcemic rabbits. Turk J Surg 2017; 33(2): 91-95

'Department of General Surgery, Bezmialem Vakif University School of Medicine, İstanbul, Turkey

${ }^{2}$ Department of General Surgery, İstanbul Training and Research Hospital, İstanbul, Turkey ${ }^{3}$ Institute of Experimental Medicine, İstanbul University, İstanbul, Turkey

${ }^{4}$ Department of Pathology, Bezmialem Vakıf University School of Medicine, İstanbul, Turkey

Address for Correspondence Yiğit Düzköylü

e-mail: dryigit@gmail.com

Received: 19.10.2015

Accepted: 04.01.2016

(C) Copyright 2017

by Turkish Surgical Association

Available online at

www.turkjsurg.com

\section{INTRODUCTION}

Hypoparathyroidism is a serious health problem that most commonly occurs as a complication of thyroid surgery. Postoperative hypoparathyroidism may be observed in three different variations such as transient (occurs within 3-6 months), protracted (occurs within 1 year) or permanent (occurs after the $1^{\text {st }}$ year) (1). Because parathyroid hormone (PTH) has multiple metabolic functions, control of hypoparathyroidism symptoms with calcium (Ca) replacement therapy can be very difficult (2). Parathyroid allotransplantation for permanent hypoparathyroidism is a relatively new option for treatment (2-4). Upon extensive literature review, it is noted that donors are selected from cadavers or patients with secondary hyperparathyroidism. Primary parathyroid adenomas are the most common cases of surgical intervention indicated in the literature due to hyperparathyroidism, but these patients have not been used as donors thus far (5-7). Cells isolated from adenomatous parathyroid tissue are superior to healthy and secondary hyperplastic cells both in quantity and proliferation rate. However, because adenoma is a benign tumor, there are some concerns about its possible behavior in recipients $(5,6)$. The potential for functional or histopathologic transformation of adenoma cells is not yet known (5-7). In this study, we aimed to pre-evaluate the usability of this tissue with xenotransplantation from human to rabbit because it has potential to be quite valuable as a cell source.

\section{MATERIAL AND METHODS}

This research was performed in Bezmialem Vakif University, and the research protocol was approved by the same university's Local Animals Ethics Committee. All protocols were in accordance with the regulations governing the care and use of laboratory animals of the declaration of Helsinki.

Seven male New Zealand white rabbits (mean weight, 3700220 g; 3700 220 g, mean age 4.5 months) without bred production were used. The rabbits were sheltered at one per cage in standard cages, with top and bottom parts made of stainless metal and sides made of woven wire. The floors of the cages were covered with wood shavings, which were changed daily. Rabbits were kept at room temperature and with adequate ventilation. Water and feeding containers were made of standard plastic, with sideways entrances. Animals were fed specially produced pellet feeds for small laboratory animals. 
Procedure for Parathyroid Tissue Donor Patient: A 49-yearold male patient was admitted to the outpatient clinic with malignant hypercalcemia (blood calcium level $>11 \mathrm{mg} / \mathrm{dL}$ ). Ultrasound evaluation of the neck revealed a $3 \mathrm{~cm}$ diameter mass inferior to the left lobe of the thyroid tissue. Parathyroid scintigraphy (Tc 99m MIBI) indicated that the mass was a parathyroid adenoma. A small Kocher neck incision was performed, and the mass was excised and then divided into two parts. One part was used for histopathologic evaluation and the other part was cryopreserved according to thetechnique described below for xenotransplantation. The mass was reported as parathyroid adenoma inthe histopathologic evaluation.

Cryopreservation and Cell Preparation: Tissue was pooled and cryopreserved in three main steps: cell isolation, cell counting (total number of cells, rate of viability) and finally storing in a liquid nitrogen tank. Tissue samples were immediately placed in ice-chilled RPMI 1640 media after removal, and the cells were isolated. The entire protocol was carried out in sterile conditions in a sterile hood. All solutions and instruments were sterilized. The tissues were gently placed in a steel filter and rinsed with PBS $+5 \%$ FCS (medium I). The tissues were then smashed with a syringe piston until the cells from whole tissues were split apart. The cells, floating in medium I, were filtered through a cell strainer. During these steps, some cells may lyse, releasing their DNA into the solution. This DNA can cause cell aggregation, which was prevented by the addition of DNase. Once whole tissue was disassociated and filtered through the cell strainer, Vi-Cell (Beckman Coulter) was used to determine viability with the trypan blue staining method. The cells were then prepared for cryopreservation with the following steps: a $500 \mu \mathrm{l} \mathrm{FBS}$ $20 \%$ DMSO (400 $\mu \mathrm{l} \mathrm{FBS+100} \mu \mathrm{l}$ DMSO) solution was prepared and gently dropped into $500 \mu \mathrm{l}$ FBS solution containing $0.25 \times 106$ cells on ice. The temperature of the solution was gradually decreased and the solution was then stored in a liquid nitrogen tank.

Transplantation: On the day of transplantation, $100 \mathrm{mg} / \mathrm{kg}$ prednisolon (Prednol-L 40 mg Ampul ${ }^{\oplus}$; Mustafa Nevzat Co, İstanbul, Turkey) was used subcutaneously as an induction dose with a continued dose of $10 \mathrm{mg} / \mathrm{kg} /$ day for all rabbits. The cell solutions were thawed by submerging in a $37^{\circ} \mathrm{C}$ water bath. After shaving and antisepsis with povidone-iodine
(Batticon 10g Pvp-iyot; Adekallaç, İstanbul, Turkey), 300,000 parathyroid cells were injected intramuscularly into the superior portion of the right back extremity of the rabbits, after the procedure injection area was signed with a marker pen. PTH, calcium (Ca) and phosphorus (P) levels were sampled on post-transplantation day 10 . On day 10 , rabbits were sacrificed and the signed injection fields were resected for histopathologic evaluation. Specimens were fixed in $70 \%$ alcohol, dehydrated, and embedded in paraffin wax. Sections were cut at a thickness of $5 \mathrm{~mm}$, stained with hematoxylin, eosin and evaluated by a pathologist experienced in endocrinology.

Primary evaluation parameters of this research are histopathologic differentiation of transplanted cells and blood PTH, Ca, P levels. The occurrence of complications related to transplantation is the secondary evaluation parameter. We used human parathyroid hormone kit in our study, which shows results under 0.5 as 'zero' and results over 1900 as 'unidentified.'

Statistics Analysis: All statistics were performed using Statistical Package for the Social Sciences version 15.0 for Windows (SPSS Inc.; Chicago, IL, USA). Continuous variables are expressed as the means \pm standard deviation (SD). Significances of the measurements of serum calcium and phosphorus levels were evaluated by the Wilcoxon test. The differences were considered statistically significant if the $p$ value was less than 0.05 .

\section{RESULTS}

Levels of PTH, Ca and P in blood from the ear veins of the rabbits before and on the $10^{\text {th }}$ day aftertransplantation before sacrificing are shown in Table 1. When the levels before and aftertransplantation were compared, the differences between the levels of PTH were statistically significant $(p<0.05)$. While Ca levels had increased, $P$ levels had decreased, but the differences for these twoparameters were not statistically significant. Mean PTH level was $0.5 \mathrm{pg} /$ $\mathrm{dL}$ before transplantation and $6.6 \mathrm{pg} / \mathrm{dL}$ after transplantation $(p<0.05)$. Mean Ca level was $14.1 \mathrm{mg} / \mathrm{dL}$, mean $P$ level was $3.5 \mathrm{mg} / \mathrm{dL}$ before transplantation, and $14.4 \mathrm{mg} / \mathrm{dL}$ and $3.3 \mathrm{mg} / \mathrm{dL}$, respectively, after transplantation $(\mathrm{p}>0.05)$. When parathyroid cells were observed histopathologically, there were no morphologic changesbefore and after transplantation (Figure 1, 2).

Table 1. Serum levels of PTH, Ca and P before and on the $10^{\text {th }}$ day after xenotransplantation

Case PTH ( pg/dL) (before) PTH ( pg/dL) (after) Ca (mg/dL) (before) Ca (mg/dL) (after) p (mg/dL) (before) p (mg/dL) (after)

\begin{tabular}{|c|c|c|c|c|c|c|}
\hline 1 & 0.7 & 17.9 & 113.7 & 14 & 3.2 & 2.9 \\
\hline 2 & 1.3 & 4.8 & 14.2 & 12.7 & 3 & 3.2 \\
\hline 3 & 1.6 & 3.9 & 15 & 13.7 & 3.6 & 4.6 \\
\hline 4 & 0 & 2 & 13.3 & 14 & 3.3 & 4 \\
\hline 5 & 0 & 4.1 & 13.8 & 16.5 & 3.4 & 2.9 \\
\hline 6 & 0 & 3.3 & 14.5 & 15.9 & 5 & 1.9 \\
\hline 7 & 0 & 10.6 & 14.3 & 14.5 & 3.5 & 4 \\
\hline Mean & 0.5 & 6.6 & 14.1 & 14.4 & 3.5 & 3.3 \\
\hline
\end{tabular}




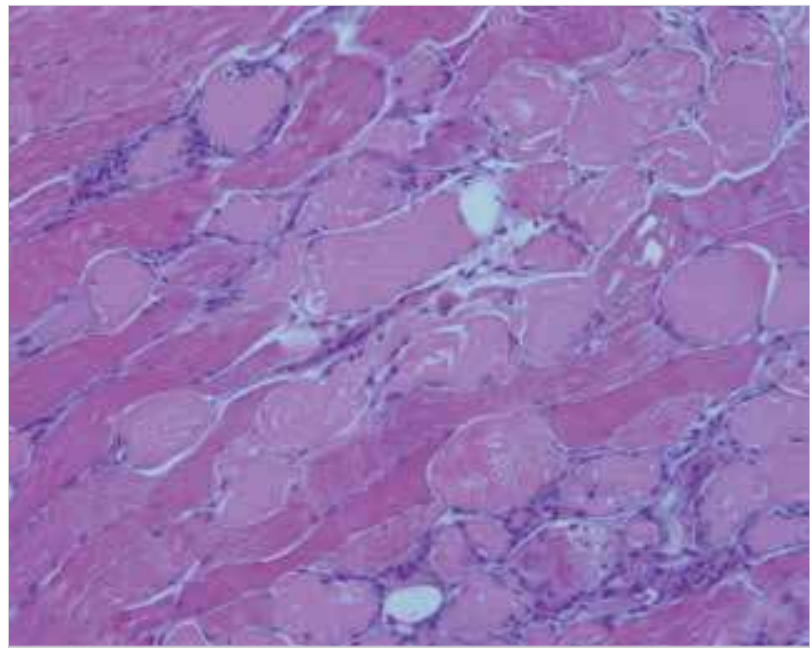

Figure 1. Parathyroid cells between the striated muscle fibers (Hematoxylin and Eosin, 40x magnification)

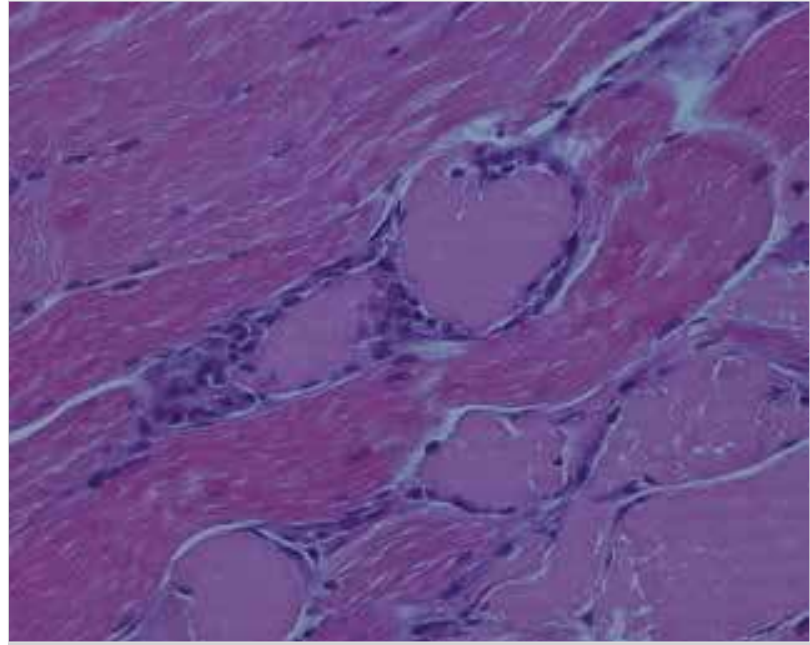

Figure 2. Parathyroid cells between the striated muscle fibers (Hematoxylin and Eosin, 200x magnification)

\section{DISCUSSION}

Because of the significant clinical symptoms of permanent hypoparathyroidism $(\mathrm{PH})$, clinicians have studied various therapeutic solutions. In long-term medical treatment, oral calcium and vitamin D or its analogues can be administered. However, it is important to deliver them in appropriate doses with regards to pharmacodynamics, the potency at the tissue level, rapidity of action, and the ease of reversal of toxicity (8). Long-term treatment with calcium and vitamin $D$ does not restore physiologic calcium homeostasis and often results in hypercalciuria, even in the face of normocalcemia, thereby increasing the risk of renal sequel (9). Additionally, the disadvantages of conventional therapy including a narrow therapeutic window, propensity for hypercalciuria and hypercalcemia, and the absence of negative feedback mechanisms have led to the investigation of new approaches, including parathyroid gland autotransplantation $(8,10,11)$.

As has been shown in various studies, parathyroid gland autotransplantation is an effective approach for reducing the incidence of permanent and transient hypoparathyroidism and is best performed in the setting of total thyroidectomy (12-14). However, it is important to remember that this approach is only possible when the removal and/or devascularization of the glands is recognized by the surgeon peroperatively. Additionally, in patients who have been operated for secondary hyperparathyroidism, autograft hyperplasia may cause recurrences (15).

In recent years, surgeons have studied various therapeutic solutions for the treatment of $\mathrm{PH}$ based on other transplantation methods. In the literature, transplantation of parathyroid glands included in total laryngeal transplantation have been reported (16). Currently, studies involving iso-, allo-, and xenotransplantation of parathyroid tissue in human and animals indicate promising results that go far beyond the preoperative autotransplantation techniques $(17,18)$. The use of cultured human parathyroid cells is an essential technique for allo- and xeno- transplantation because it provides better engraftment of parathyroid cells by means of better revascularization and a decrease in the expression of the major histocompatibility complex on parathyroid cells $(2,19,20)$. To overcome organ rejection in parathyroid allotransplantation, a number of methods have been proposed, such as short-term immunosuppression and immune-alteration by depletion of passenger leukocytes or preoperative organ culture but unfortunately, those approaches resulted in prolonged but insufficient graft function (21-23).

At present, tissues derived from patients with hyperplastic parathyroid glands are frequently used because of their numerous cells. Parathyroid hyperplasia is a clinical condition that is often coexistent with chronic renal failure (24-26). However, because the incidences of Hepatitis C and Hepatitis B viral infections in this patient population are high which prevent researchers from performing transplantations, even this limited number of patients cannot be used effectively as donors (27-30).

In the literature, it is shown that the average lifetime of these tissues derived from this donor population is no longer than 6 months, and this interval may be further prolonged in tissues derived from parathyroid adenoma (29). In this study, we transplanted adenomatous parathyroid cells from one human patient into rabbits and evaluated functional and histopathologic features. In each rabbit, increases in PTH levels were found to be statistically significant. Ca levels were also found to be increased and $P$ were decreased, but the increase was not found to be statistically significant. These promising results show that, similar to theresults of studies with hyperplastic tissues, adenomatous transplants do not result in an uncontrolledincrease in either PTH or Ca levels. In addition, morphologic differences were not detected at theend of the study.

Although there are well-known published studies concerning transplantation of healthy parathyroid tissue to humans, there has not yet been a study about transplantation of adenomatous cells because of the malignant potential of parathyroid adenomas. In our experimental study, we evaluated the development and potential malignant transformation of adenomatous human parathyroid tissue transplanted into rabbits, with a successful combination of tissue culture passage and cryopreservation with immunosuppression. 


\section{Limitations of the study}

Although our results were favorable, the effects were shortterm. There are two reasons for this limitation. First, long-term immunosuppression in rabbits can lead to rapid metabolic disorders, which results in early deaths. Second, the cells that were transplanted in the muscle tissue could migrate from their initial localization, which may make histopathologic assessment impossible for us.

\section{CONCLUSION}

Our results show that adenomatous parathyroid cells function in the short-term without any morphologic transformation, which can support the consideration of a safe and alternative allotransplantation method of human adenomatous parathyroid tissue and may function as a preliminary work in this field of study.

Ethics Committee Approval: Ethics committee approval was received for this study from Bezmialem Vakıf University Animal Experiments Local Ethics Committee (Number 2013/99).

Informed Consent: Not required in this study.

Peer-review: Externally peer-reviewed.

Author Contributions: Concept - E.A.,Y.D.; Design - E.A., I.C.; Supervision - E.A.,Y.D.; Resource - I.C., N.P.; Materials - I.C., N.P., E.A.; Data Collection and/or Processing - Y.D., N.P.; Analysis and/or Interpretation - E.A., I.A.; Literature Search - Y.D., E.A.; Writing Manuscript - E.A., Y.D.; Critical Reviews - E.A.,Y.D.

Conflict of Interest: No conflict of interest was declared by the authors.

Financial Disclosure: The authors declared that this study has received no financial support.

\section{REFERENCES}

1. Jimenez AL, Hernandez JRH. Parathyroid transplantation. Endocrinol Nutr 2013; 60: 161-163.

2. Hasse C, Klock G, Schlosser A, Zimmermann U, Rothmund M. Parathyroid allotransplantation without immunosuppression. Lancet 1997; 350: 1296-1298. [CrossRef]

3. Saxe A. Parathyroid transplantation: a review. Surgery 1984; 95 : 507-509.

4. Alfrey EJ, Perloff LJ, Asplund MW, Dafoe DC, Grossman RA, Bromberg JS, et al. Normocalcemia thirteen years after successful parathyroid allografting in a recipient of a renal transplant. Surgery 1992; 111: 234-237.

5. Tsuji K, Fuchinoue S, Kai K, Kawase T, Kitajima K, Sawada T, et al. Culture of human parathyroid cells for transplantation. Transplant Proc 1999; 31: 2697-2700. [CrossRef]

6. Bloom AD, Economou SG, Baker JW, Gebel HM. Prolonged survival of rat parathyroid allografts after preoperative treatment with cyclosporine A. Curr Surg 1987; 44: 205-209.

7. Schulze $M$, Fandrich $F$, Ungefroren $H$, Kremer B. Adult stem cellsperspectives in treatment of metabolic diseases. Acta Gastroenterol Belg 2005; 68: 461-465.

8. Walker Harris V, Jan De Beur S. Postoperative hypoparathyroidism: medical and surgical therapeutic options. Thyroid 2009; 19: 967-973. [CrossRef]

9. Arlt W, Fremerey C, Callies F, Reincke M, Schneider P, Timmermann $W$, et al. Well-being, mood and calcium homeostasis in patients with hypoparathyroidism receiving standard treatment with calcium and vitamin D. Eur J Endocrinol 2002; 146:215-222. [CrossRef]

10. Khan MI, Waguespack SG, Hu MI. Medical management of postsurgical hypoparathyroidism. Endocr Pract 2011; 17: 967-969. [CrossRef]

11. Pattou F, Combemale F, Fabre S, Carneille B, Decoulx M, Wemeau $\mathrm{JL}$, et al. Hypocalcemia following thyroid surgery: incidence and prediction of outcome. World J Surg 1998; 22: 718-724. [CrossRef]

12. Moffett JM, Suliburk J. Parathyroid autotransplantation. Endocr Pract 2011; 17: 83-89. [CrossRef]

13. Testini $M$, Rosato $L$, Avenia $N$. The impact of single parathyroid gland autotransplantation during thyroid surgery on postoperative hypoparathyroidism: a multicenter study. Transplant Proc 2007; 39: 225-230. [CrossRef]

14. Olson JA Jr, DeBenedetti MK, Baumann DS, Wells SA Jr. Parathyroid autotransplantation during thyroidectomy results of longterm follow-up. AnnSurg 1996; 223: 472-478. [CrossRef]

15. Sarı E, Hacıyanlı M, Koruyucu MB, Dere Ö, Dülgeroğlu $O$, Kumkumoğlu Y, et al. An important cause of recurrent hyperparathyroidism: autograft hyperplasia. JDE Endokrin 2014; 11: 22-25.

16. Sakallığlu Ö. Laryngeal Transplantation. Turk Arc Otorhinolaryngol 2015; 53: 128-132. [CrossRef]

17. Hasse C, Schrezenmeir J, Stinner B, Schark C, Wagner PK, Neumann $K$, et al. Successful allotransplantation of microencapsulated parathyroids in rats. World J Surg 1994; 18: 630-634. [CrossRef]

18. Hasse C, Zielke A, Klöck G, Barth P, Schlosser A, Zimmermann U, et al. First successful xenotransplantation of microencapsulated human parathyroid tissue in experimental hypoparathyroidism: long-term function without immunsuppresion. J Microencapsul 1997; 14: 617-626. [CrossRef]

19. Tolloczko T, Wozniewicz B, SawickiA, Gorski A. Allotransplantation of human culture parathyroid cells: present status and perspectives. Transplant Proc 1997; 29: 998-1001. [CrossRef]

20. Bjerneroth G, Juhlin C, Rastad J, Akerström G, Klareskog L. MHC class I and II antigen expression on parathyroid cells and prospects for their allogenic transplantation. Transplantation 1993; 56: 717-721. [CrossRef]

21. Timm S, Otto C, Begrich D, Moskalenko V, Hamelmann W, Ulrichs $\mathrm{K}$, et al. Immunogenicity of parathyroid allografts in the rat: immunosuppressive dosages effective in passenger leukocyte-rich small bowel transplants are not effective in parathyroid gland transplants with few passenger leukocytes. Langenbecks Arch Surg 2004; 389: 46-52. [CrossRef]

22. Woźniewicz B, Migaj M, Giera B, Prokurat A, Tołłoczko T, Sawicki $A$, et al. Cell culture preparation of human parathyroid cells for allotransplantation without immunosuppression. Transplant Proc 1996; 28: 3542-3544.

23. Moskalenko V, Ulrichs $\mathrm{K}$, Kerscher A, Blind E, Otto C, Hamelmann $W$, et al. Preoperative evaluation of microencapsulated human parathyroid tissue aids selection of the optimal bioartificial graft for human parathyroid allotransplantation. Transpllnt 2007; 20: 688-696. [CrossRef]

24. Timm S, Otto C, Begrich D, Illert B, Hamelmann W, Ulrichs K, et al. Short-term immunosuppression after rat parathyroid allotransplantation. Microsurgery 2003; 23: 503-507. [CrossRef]

25. Hasse C, Bohrer T, Barth P, Stinner B, Cohen R, Cramer H, et al. Parathyroid xenotransplantation without immunosuppression in experimental hypoparathyroidism: long-term in vivo function following microencapsulation with a clinically suitable alginate. World J Surg 2000; 24: 1361-1366. [CrossRef]

26. Nawrot I, Woźniewicz B, Tołłoczko T, Sawicki A, Górski A, Chudziński W, et al. Allotransplantation of cultured parathyroid progenitor cells without immunosuppression: clinical results. Transplantation 2007; 83: 734-740. [CrossRef]

27. Drüke TB. The pathogenesis of parathyroid gland hyperplasia in chronic renal failure. Kidney Int 1995; 48: 259-272. [CrossRef] 
28. Silver J, Sela SB, Naveh-Many T. Regulation of parathyroid cell proliferation. Curr Opin Nephrol Hypertens 1997; 6: 321-326. [CrossRef]

29. Drüeke TB, Zhang P, Gogusev J. Apoptosis: background and possible role in secondary hyperparathyroidism. Nephrol Dial Transplant 1997; 12: 2228-2233. [CrossRef]
30. Carneiro MAS, Martins RMB, Teles AS, Silva AS, Lopes Carmen L, Cardoso DDP, et al. Hepatitis $C$ prevalence and risk factors in hemodialysis patients in Central Brazil: a survey by polymerase chain reaction and serological methods. Mem Inst Oswaldo Cruz 2001; 96: 765-769. [CrossRef] 